Ronald W. Busuttil, M.D., Ph.D.

Professor of Surgery

Director, Liver Transplantation Program

University of California. Los Angeles

School of Medicine

Los Angeles, California

Goran B. Klintmalm, M.D., Ph.D.

Professor of Surgery

Director of Transplantation

Department of Surgery

Baylor University Medical Center

Dallas, Texas 


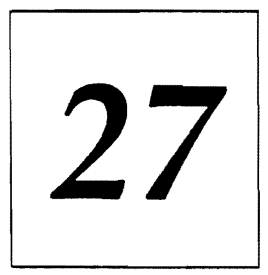

\section{Cell Migration, Chimerism, and Graft Acceptance, With Particular Reference to the Liver}

Thomas E. Starzl, MD, PhD, Anthony J. Demetris, MD, Massimo Trucco, MD, Noriko Murase, MD, Camillo Ricordi, MD

Improvements in the prevention or control of rejection of the kidney and liver are largely interchangeable and then applicable with little modification to thoracic and other organs (see Chapter 50 ). The mechanism by which antirejection treatment permits any of these grafts to be accepted, however, has been an immunological enigma. ${ }^{1-8}$ We have proposed ${ }^{9-15}$ that the exchange of migratory leukocytes between the transplant and the recipient with consequent long-term cellular chimerism in both is the basis for acceptance of all whole organ allografts and xenografts (Fig $27-1$ ). Although such chimerism was first demonstrated as recently as mid-1992, the observations have increased our insight into transplantation immunology and have encouraged the development of alternative therapeutic strategies.

\section{LOCAL (GRAFT) CHIMERISM}

\section{The Liver}

The first unequivocal evidence that whole organ grafts in humans become genetic composites (local chimerism) was obtained in 1969 with karyotyping techniques in female recipients of livers obtained from male cadaveric donors. These studies were done by K.A. Porter of St. Mary's Hospital and Medical School in London on allografts from the first long-surviving patients in the University of Colorado liver series. ${ }^{16,17}$ Postoperatively, both the hepatocytes and the endothelium of the major blood vessels of the grafts retained their donor sex, whereas the entire macrophage system, including the Kupffer cells, was replaced with recipient female cells (identified by their characteristic Barr bodies) within 100 days (Fig 27-2, middle). The assumption for many years was that the composite (chimeric) structure of the hepatic allograft was a special feature of this organ.

\section{Other Organs}

The illusion of the uniqueness of the hepatic graft was dispelled in 1991 with the demonstration, first in rat models ${ }^{18}$ and then in human intestinal grafts, ${ }^{19}$ that the epithelium and vascular endothelium remained donor specific, whereas lymphoid, dendritic, and other leukocytes were replaced by recipient cells in the lamina propria, Peyer's patches, and mesenteric nodes. As with the liver, the chimerism of the intestinal graft was made easy to demonstrate because of its large constituency of lymphoreticular cells.

The suspicion that this transformation must be occurring with other kinds of whole organ grafts was promptly confirmed with the kidney ${ }^{12,20}$ and with the thoracic organs. $^{21-23}$

\section{DISCOVERY OF SYSTEMIC CHIMERISM}

\section{Circumstantial Evidence}

Twenty-two years passed between the discovery of the chimerism of the transplanted liver and that of the intestine; during this period, several clinical reports noted the local chimerism in long-surviving human kidney allografts ${ }^{20,24-26}$ and in subhuman primates. ${ }^{27}$ Throughout this time, the tacit or explicit assumption was that the cells departing the liver or kidney had been destroyed. With the evidence that the local chimeric changes occurred in all kinds of grafts. the burning question became what happened to the donor cells that had disappeared from the grafts. Much earlier circumstantial evidence existed that donor leukocytes migrating from the engrafted organs were still present in the body; however, this evidence had been largely ignored, forgotten, or misinterpreted.

Kidney Transplantation. The results of exhaustive skin test studies (tuberculin, histoplasmin, blastomycin, and 
Figure 27-1 The mutual exchange of migratory immunocytes from the graft and the recipient after organ transplantation under potent pharmacological immunosuppression. GVH = graft versus host; $H V G=$ host versus graft. (Reprinted from Immunology Today, 14, Starzl TE, Demetris AW, Murase N, et al, Donor cell chimerism permitted by immunosuppressive drugs: A new view of organ transplantation, 326-332, Copyright 1993, with kind permission from Elsevier Science Ltd. The Boulevard, Langford Lane, Kidlington, OX5 1GB, UK.)

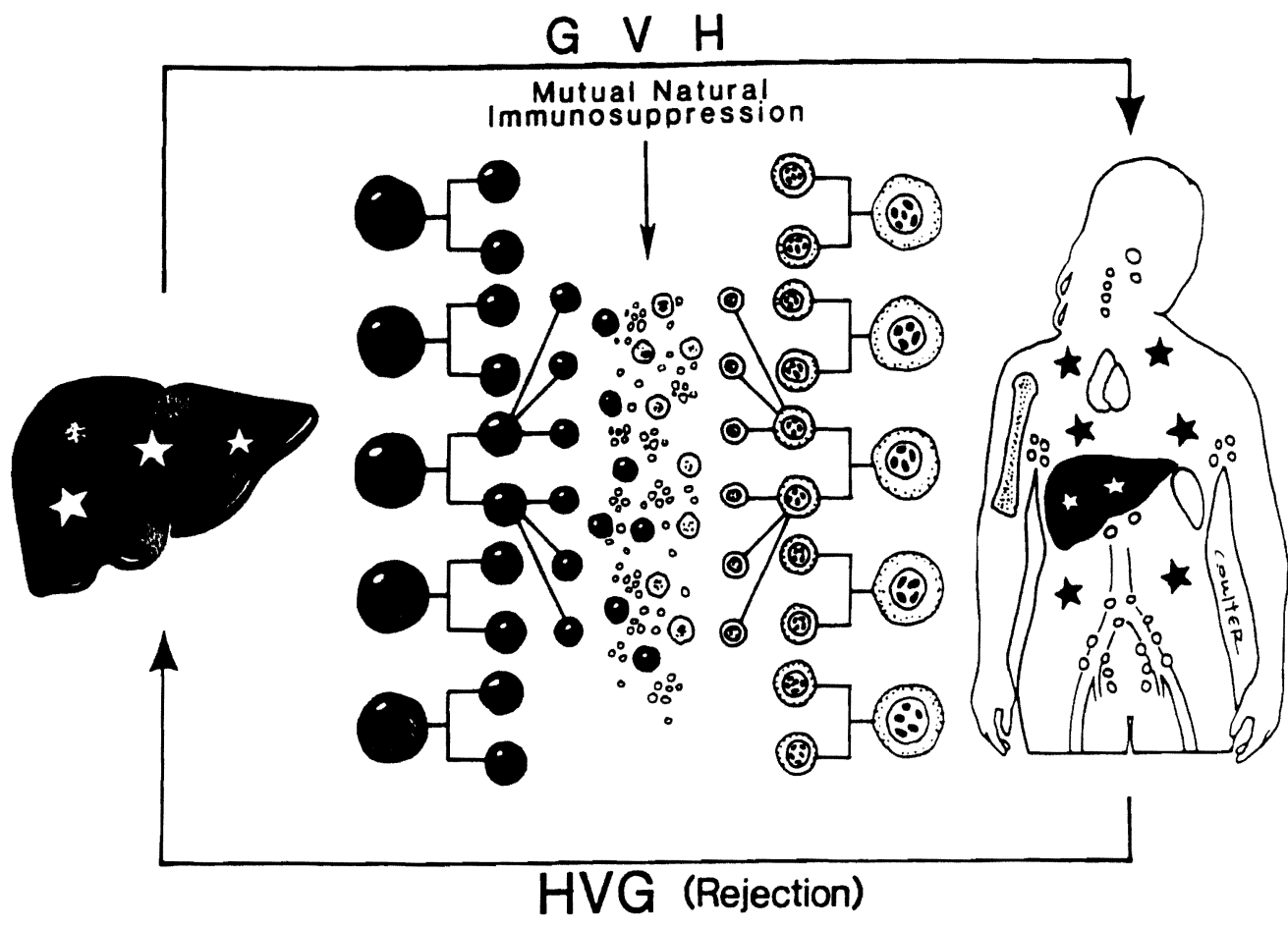

coccidioidin; and tests for mumps, candidiasis, and trichophytosis) in our early Colorado kidney recipients and their donors provided a clue to the fate of the replaced donor cells, ${ }^{28}$ but one that was considered implausible at the time. Preoperatively, skin test reactions of recipients were negative and those of donors were positive; postoperatively, $77 \%$ of the recipients had positive skin test results (Fig $27-3$ ). When this did not occur (in the other $23 \%$ ), it meant that the kidney transplantation had failed. It was speculated that the secondary acquisition of the positive skin test results was "caused by adoptive transfer of donor cellular immunity by leukocytes in the renal graft vasculature and hilar lymphoid tissue." 28 However, the implica- tion that cells from the graft had migrated to recipient tissues was considered untenable nearly 30 years ago because the kidney was then thought to be a leukocyte-poor organ. Consequently, the flash of potential insight faded, in spite of the fact that the "transfer factor" of Lawrence 29 was suggested as a possible amplification device for the ostensibly small number of donor cells.

Liver Transplantation. Clues to the development of systemic chimerism were also ignored after liver replacement and were correctly interpreted only later. When the composite structure of liver allografts was discovered in 1969, the continued viable presence outside the liver of the de-
Figure 27-2 Steps in the understanding of liver transplantation. Historical view (left), realization in 1969 that the liver graft became a genetic composite or chimera (middle), and proof in 1992 of systemic chimerism (right). (From Starzl TE, Demetris AJ. Trucco M, et al. Cell migration and chimerism after whole organ transplantation: The basis of graft acceptance.

Hepatology 17:1127-1152, 1993.)

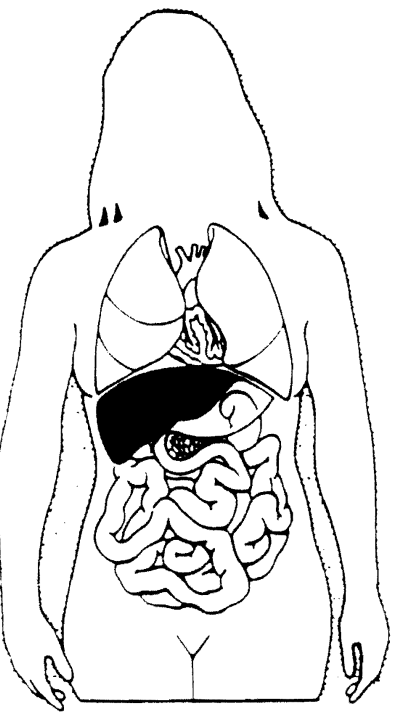

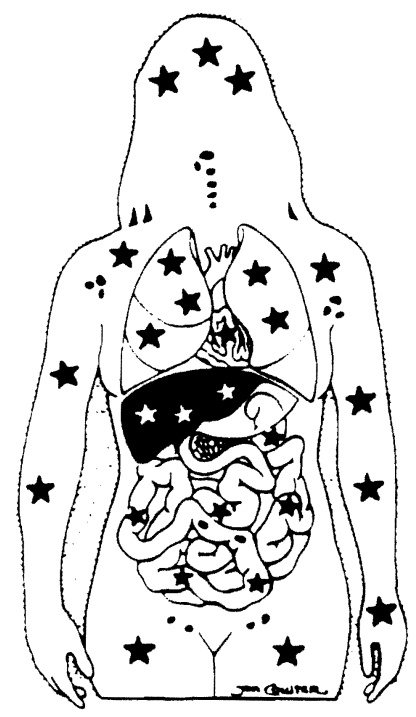




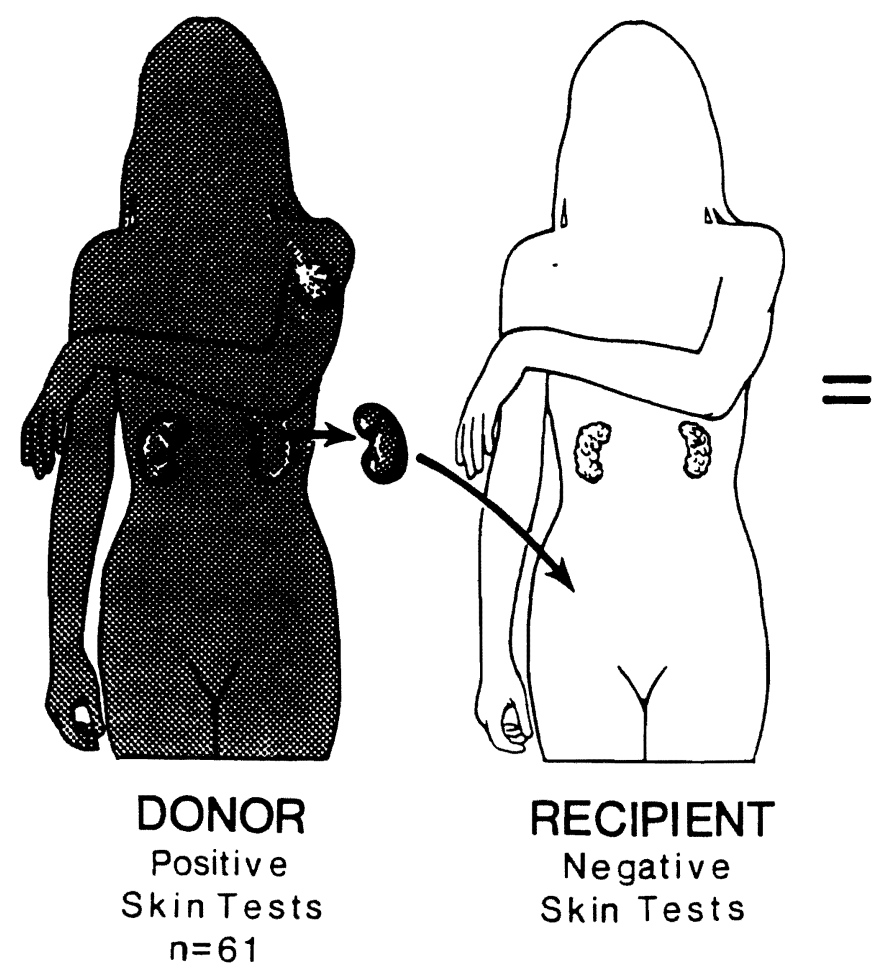

parted donor cells was signaled by the appearance and maintenance in the recipient blood of new donor-specific immunoglobulin $(\mathrm{Gm})$ types. ${ }^{17,}{ }^{30}$ Fifteen years later, emigrant cells from the graft were proposed to be the source of anti - red blood cell antibodies that developed in patients who were the recipients of livers from donors with $A B O$ nonidentity. ${ }^{31}$ Subsequently, Davies et $\mathrm{al}^{32}$ showed the appearance in liver recipients of new circulating, donor-specific class I antigens, and they attributed these antigens to synthesis by the graft hepatocytes rather than to migratory passenger leukocytes. However, because these molecules were known to come from bone marrow-derived macrophages, dendritic cells, or both, ${ }^{33-35}$ they presumably had the same donor origin as the additional Gm types and anti-red blood cell antibodies after the completion of cell migration to extrahepatic sites.

\section{Direct Evidence of Chimerism}

In 1993, Murase et al ${ }^{36,37}$ showed with flow cytometry that the stromal leukocytes leaving the small bowel allografts in rat recipients treated with a short course of FK506 migrated in large numbers through vascular routes to widely distributed host lymphoid tissues. This created a state of systemic mixed allogeneic chimerism for at least 45 days that was free of lethal or even detectable graft-versus-host disease (GVHD), except in strain combinations in which the Brown Norway (BN) rat was the recipient. ${ }^{36-38} \mathrm{Be}$ cause the circulating cells detectable with flow cytometry were not studied for more than 45 days and because their number diminished throughout this time, the ultimate fate of these cells remained in doubt during all of 1991 .

The next. and as it turned out decisive, step was to look for evidence of chimerism in human recipients of kidneys,

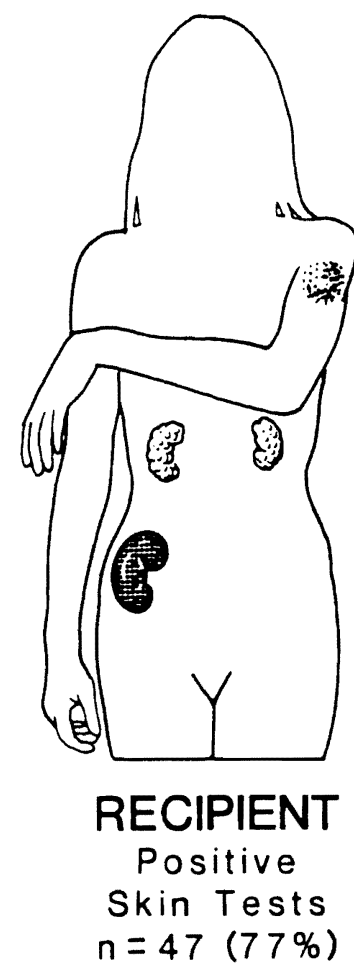

Figure 27-3 Transfer of positive skin test results from kidney donors to recipients in patients at the University of Colorado. 1962-1964. ${ }^{28}$ Although inexplicable at the time, these observations reflected adoptive transfer after cell migration, repopulation, and chimerism. (From Starzl TE, Demetris AJ, Trucco $\mathrm{M}$, et al. Cell migration and chimerism after whole organ transplantation: The basis of graft acceptance. Hepatology 17:11271152. 1993.)

livers, and other organs whose successful transplantation had been performed many months or years earlier. This required more sophisticated and sensitive techniques than had been previously used for this purpose. The search from April through July 1992 for chimeric cells in the tissues of these whole organ recipients was made feasible by the distinctive features of two chromosomes. In females who had been given an organ from a male donor, the presence in recipient tissues (or blood) of cells with the $Y$ chromosome was considered unequivocal evidence of systemic chimerism. Alternatively, probes were used that detected human leukocyte antigen (HLA) alleles of chromosome 6. For study of either the $\mathrm{Y}$ chromosome or chromosome 6 , one or the other of two technologies, and usually both, were exploited.9-14

One of these technologies was cytostaining, which allows the location and morphological characterization of phenotypically distinct donor and recipient cells. The cytostaining for the $Y$ probe was accomplished by a fluorescence method after in situ hybridization (Fig $27-4$ ). The immunostaining for the HLA markers was done with indirect immunofluorescence, an avidin-biotin-complex immunoperoxidase method, or both and used monoclonal antibodies to class I and class II antigen phenotypes present in the donor but not the recipient.

The other technology was polymerase chain reaction. which distinguishes donor from recipient DNA. ${ }^{9-14}$ In the polymerase chain reaction search for the $Y$ chromosome, oligonucleotides specific for the satellite region of the $Y$ chromosome centromere $\mathrm{Y}-\mathrm{A}$ and for the sex-determining region of the $Y$ chromosome were used as primers to determine the presence of male DNA in the female recipient tissues. The polymerase chain reaction tests for donorand recipient-specific HLA alleles of chromosome 6 were performed by preliminary generic amplification of the 

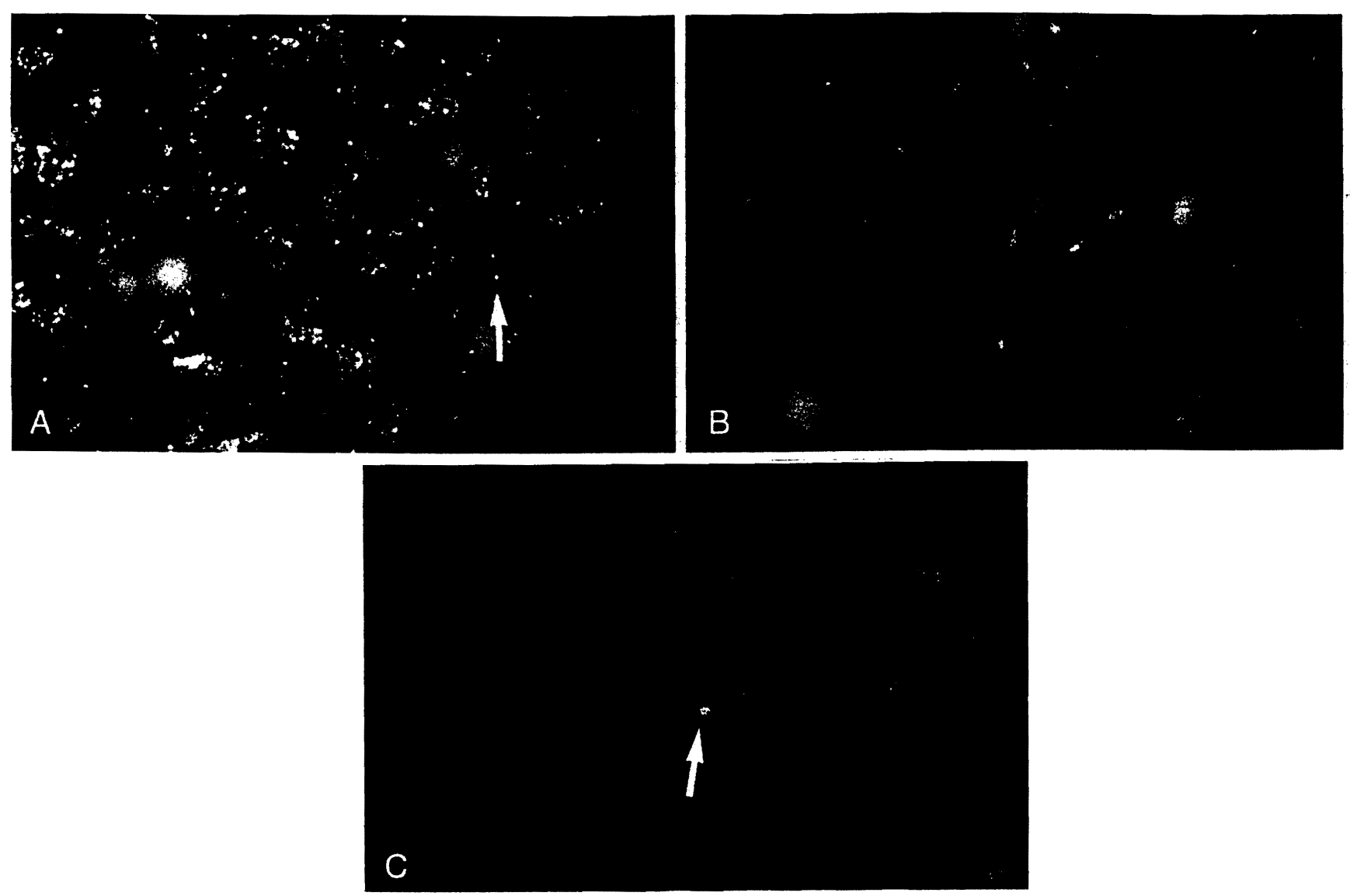

Figure 27-4 Studies of patient OT (othotopic transplant) $64,191 / 2$ years after her liver replacement from a male donor. Fluorescence after in situ hybridization with the DYZ1 probe for the $Y$ chromosome was used to differentiate male from female cells. $A$, The allograft liver was used as a positive control. About $60 \%$ of hepatocytes and a few sinusoidal cells retained the donor genotype (arrow); the $Y$ chromosome in the negative hepatocytes was likely excluded from the 2- $\mu \mathrm{m}$-thick sectioning plane. The yellow cytoplasmic material is autofluorescence $(X 250)$. B. Oil immersion microscopy was used to illustrate the variety of signals obtained in the liver; these formed a beaded to reticular pattem, often at the periphery of the nucleus $(\times 1000)$. C. Skin biopsy findings show that spindle-shaped stromal cells with a similar signal for the $Y$ chromosome were sparsely distributed in the $0.5-$ to $1-\mathrm{cm}$ slide sections $(\times 1000)$. ( $A$ to $C$ from StarzI TE, Demetris AJ, Trucco $M$, et al. Cell migration and chimerism after whole organ transplantation: The basis of graft acceptance. Hepatology 17:1127-1152. 1993.)

DRB gene. followed by allele-specific amplification and testing (Fig 27-5).

Human Kidney Recipients. These patients included some who had participated in the skin test studies nearly 3 decades before. By this time, they had become part of an elite group of forerunners bearing the longest continuously surviving kidney grafts in the world. ${ }^{39}$ Of the five who were studied $27-29$ years after transplantation, one had stopped immunosuppression 12 years earlier and the others were still taking azathioprine with or without prednisone. The distinction of donor from recipient cells was feasible because all five patients had received HLAincompatible kidneys; in two cases, the kidneys had come from donors of the other sex.

Low-level chimerism was found in the host tissues of all five of these kidney recipients. Biopsy specimens of the allografts showed that the cells that departed from the trans- plants were replaced by similar cells from the host. Thus, in addition to systemic chimerism, these patients were shown to have chimeric kidney grafts composed of cells with two different genomes. ${ }^{12,20}$

Human Liver Recipients. As with the kidney recipients, most of the patients in a cohort of 25 liver recipients studied for chimerism were clinically well and fully immunocompetent by conventional in vitro testing when they were studied between 2 and 22 years after transplantation under azathioprine- or cyclosporine-based immunosuppression. ${ }^{14}$

Donor cell chimerism was found with cytochemical or polymerase chain reaction techniques in all 25 patients in locations that included the skin. lymph nodes, heart. lungs, spleen, intestine, kidneys, bone marrow, and thymus. Chimeric cells were present in larger numbers at any given site than they were in the long-surviving kidney recipients being studied at the same time. 


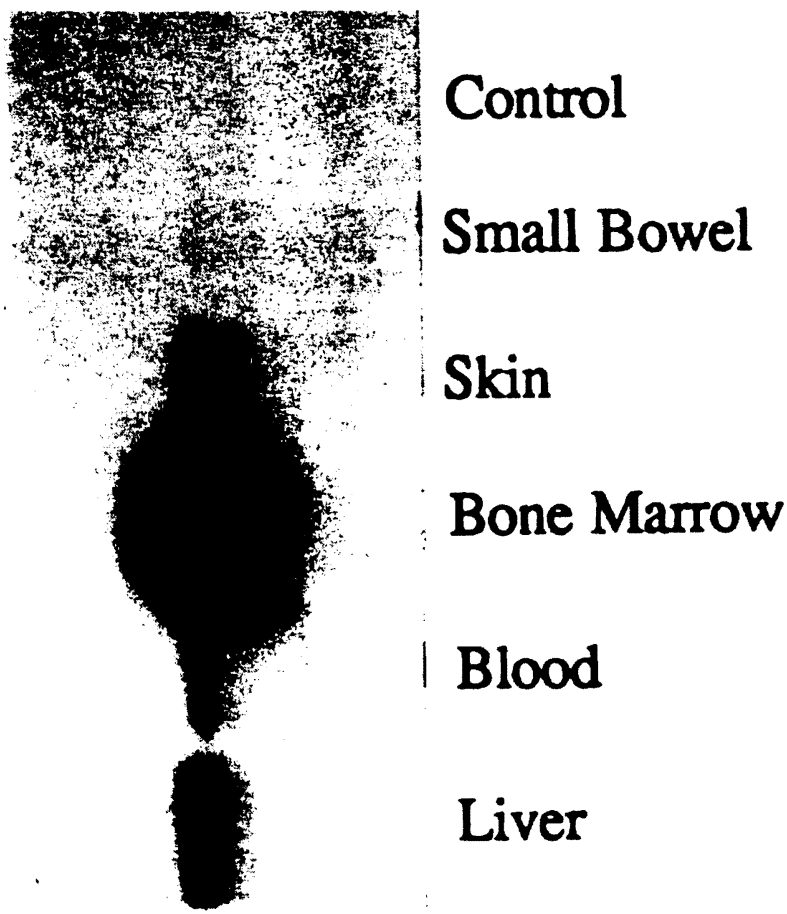

Figure 27-5 Detection of chimerism by molecular human leukocyte antigen (HLA) class II typing in various tissues after liver transplantation in a patient with type I Gaucher's disease. The illustration shows southern blot analysis of DR1-specific amplification of the DNA extracted from small bowel, skin, bone marrow, blood, and liver. The denaturated DNA present on the nylon membrane was hybridized to a radioactively labeled DR1 (donor)-specific oligonucleotide probe (7001). In the case of the liver, only $1 / 100$ of amplification product was used. $\mathrm{C}=$ negative control of the polymerase chain reaction amplification. (From StarzI TE, Demetris AJ, Trucco M, et al. Cell migration and chimerism after whole organ transplantation: The basis of graft acceptance. Hepatology 17:1127-1152, 1993.)

\section{CELL TRAFFIC AND SITES OF DONOR-RECIPIENT IMMUNOLOGICAL INTERACTIONS}

The early events leading to the chimeric state after liver transplantation have been studied in rats ${ }^{15}$ and mice, ${ }^{41}$ including the pathways of passenger leukocyte dissemination. Within minutes or hours, these cells leave the liver and migrate to the spleen, lymph nodes, thymus, and probably bone marrow, where they are destroyed by rejection in most animal models except those that use mice as subjects. However, under temporary immunosuppression in rats (FK506 daily for 2 weeks), these mononuclear cells pause for about 2 weeks in the lymphoid organs but then break out and move secondarily to all recipient tissues ${ }^{15}$ (Fig $27-6$ ). Rat liver recipients treated in this way (for example. Lewis [LEW] to BN) survive indefinitely without further treatment and retain their graft and systemic chimerism.

Interestingly, cell migration and chimerism with permanent survival of the engrafted liver occur without any immunosuppression in some rat strain combinations; of these combinations. BN to LEW has been most completely studied. ${ }^{6}$ but graft survival occurs without treat-

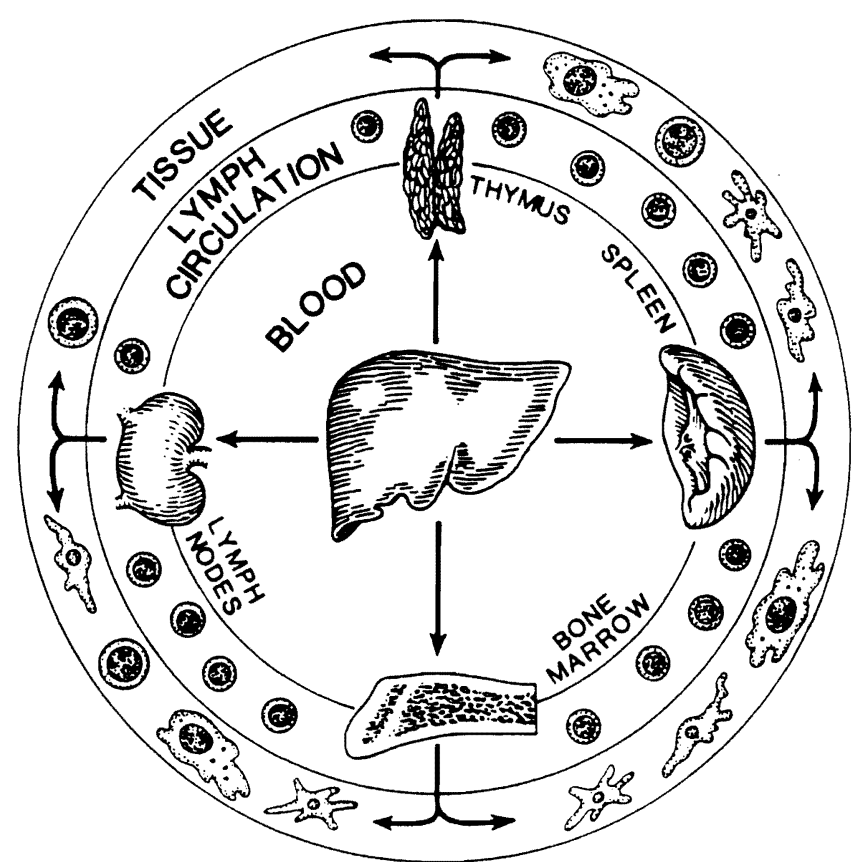

Figure 27-6 The dissemination of passenger leukocytes from the graft (rat liver in these experiments) to the central lymphoid organs; these leukocytes become ubiquitous after a brief pause. The events are similar to those after successful bone marrow transplantation.

ment in virtually all mouse strain combinations no matter how severe the histoincompatibility. ${ }^{41}$ These nonrejecting liver recipients in either species and those whose liver acceptance is induced with immunosuppression can receive skin, a kidney, or a heart from the original donor strain but no other strain (donor-specific nonreactivity). This kind of evidence has indicated that the heavy endowment of the liver with potentially migratory leukocytes is the basis for the well-known but previously inexplicable phenomenon of hepatic tolerogenicity.

\section{Hepatic Tolerogenicity}

Our hypothesis is that cell migration and repopulation is the central mechanism of acceptance of all whole organ grafts. ${ }^{9-15}$ Although this is a generic process, there are quantitative differences between organs in the density of the potentially migratory dendritic cells, macrophages. and lymphoid collections (Fig 27-7). The heavy endowment of the liver with the foregoing leukocyte lineages (including Kupffer cells) is a particularly striking feature that invites further speculation about the role of these cells in the well-known tolerogenicity of this organ.

The immunological advantage of the liver relative to other organs includes a greater ease of inducing the acceptance of liver allografts or xenografts either after a limited course of immunosuppression $\mathrm{n}^{4.6 .40 .42}$ or, in swine $\mathrm{e}^{43-45}$ and some rat strain combinations, ${ }^{46,47}$ with no treatment at all. In addition, the transplanted liver graft is relatively resistant to the preformed antigraft antibodies that cause hyperacute rejection of the kidney and heart. ${ }^{48-51}$ Another quality is the liver's unusual ability to induce a state of unresponsiveness to other tissues and organs transplanted 
concomitantly or subsequently from the donor or donor strain $^{46,49,52}$ and even to shield these organs from the hyperacute rejection caused by preformed allospecific ${ }^{51}$ or xenospecific ${ }^{33}$ antidonor antibodies. In all of these circumstances, the liver can quickly transform the recipient environment to one more favorable to all donor tissues, including itself. All of these qualities of the liver are evident in practically every mouse strain combination, no matter what the degree of histoincompatibility. ${ }^{41}$

The foregoing observations have been attributed to hepatic tolerogenicity incorrectly, we believe, because the term implies that the hepatocytes are responsible. We have proposed that the crucial variable distinguishing the tolerogenicity of one organ graft from that of another under effective immunosuppression (or, in some animal models, with no treatment) is its leukocyte, not its parenchymal component. ${ }^{9-15,41}$ This is a reversal of the immunogenic role described classically for the passenger leukocytes. ${ }^{54-67}$ Thus, because of the dense constituency of these migratory leukocytes, the liver is high on the favorable tolerogenic list, with the lung and intestine following and the kidney and heart bringing up the rear (see Fig 27 -7). Experimental studies showing the less striking tolerogenicity of the lymphoreticular-rich spleen, ${ }^{68-70}$ the intestine, ${ }^{18}$ and the lung ${ }^{71,} 72$ are compatible with this generalization.

\section{Tolerogenicity of Leukocyte-Poor Organs}

By the end of 1992, it was appreciated that all whole organs underwent the same process of potential tolerance induction as did the liver, although the dynamics of organs other than the leukocyte-rich intestine were not as easy to study ${ }^{18,} 19,36,{ }^{37}$ However, the same kind of traffic, in the context of alloactivation and rejection rather than tolerization, had been well worked out earlier with the so-called lymphoid-poor organs, which included the kidney. Studies in untreated animals have shown that the alloreaction starts in two general sites: peripherally in the graft and centrally in the recipient lymphoid tissues.

In a complete study of untreated rat kidney recipients performed in 1981, Nemlander and associates ${ }^{73}$ demonstrated extensive leukocyte migration. If the investigators had given one or two doses of cyclosporine in their kidney transplantation experiments (which were with an "easy" strain combination) and had followed the animals further, they almost certainly would have uncovered the events of cell migration and long-term repopulation that waited another dozen years for exposure with the liver. ${ }^{15}$ Larsen et $\mathrm{al}^{74}$ found that donor dendritic cells from heterotopic cardiac allografts were released into the circulation, where they eventually homed into the $T$ cell areas of the recipient spleen. In the spleen, the donor cells were found to initiate the proliferation of recipient cells. and vice versa. ${ }^{73-77}$ This reaction might be thought of as an in vivo mixed lymphocyte response: it epitomizes central allosensitization with potential tolerization.

Allosensitization and tolerization presumably also occur within the graft. Forbes et $\mathrm{al}^{76}$ showed that clustering of recipient lymphocytes occurs around donor dendritic cells in the interstitium of heart grafts, within a few days after transplantation. The recipient lymphoid cells undergo blastogenesis and proliferate within these clusters.

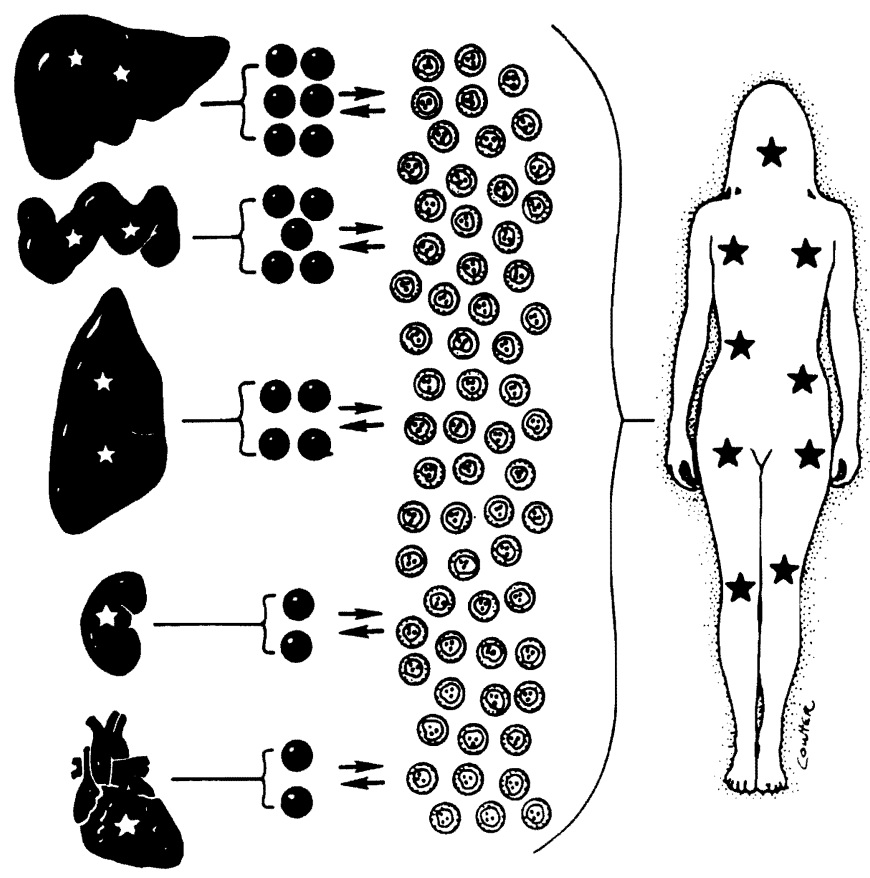

Figure 27-7 The explanation for the variable ability under immunosuppression to induce the acceptance and ultimately tolerance of different organs. We postulate that the dendritic leukocyte is the single most important, although not the only, tolerogenic cell. The tissue content of these potentially migratory cells is liver > intestine > lung > kidney and heart. (From Starzl TE, Demetris AJ, Trucco M, et al. Cell migration and chimerism after whole organ transplantation: The basis of graft acceptance. Hepatology 17:1127-1152, 1993.)

Demetris et al have described analogous events in rat livers being rejected. ${ }^{75}$

In human recipients of kidney grafts ${ }^{78,79}$ under cyclosporine plus prednisone immunosuppression, Hayry and von Willebrand noted what appeared to be a bidirectional mixed lymphocyte response in needle aspiration biopsy specimens. When collected blast cells were studied with the Staphylococcus aureus assay and alloantibodies to nonshared donor and recipient allelic specificities, most of the blast cells in some cases were derived from the donor; alternatively, the response was split, "resembling a bidirectional mixed lymphocyte reaction in vitro."78

In these models, the difference from the experiments with liver transplantation appears to be quantitative rather than fundamental. With the smaller number of passenger leukocytes, there is a greater tendency to allosensitization and less tendency to tolerogenicity. Nevertheless, Corry et $\mathrm{a}^{80}$ and Russell et $\left.\mathrm{a}\right|^{81}$ showed that tolerance without drug induction could be induced by heart and kidney transplantation between weakly major histocompatibility complex-incompatible strains of mouse recipients.

\section{FUNCTIONAL CONSEQUENCES OF MICROCHIMERISM}

Questions have been raised regarding whether the lowlevel chimerism found in our long-surviving patients and experimental animals is an irrelevant histopathological curiosity or a condition with immunological significance. Such questions appear naive in view of Russell's elegant formal proof of the association of chimerism with ac- 
quired tolerance as well as runt disease. ${ }^{82}$ However, the skepticism was generated by the small numbers of chimeric donor cells in the recipient tissues of the patients and animals in our studies. We have called this condition microchimerism, a term introduced in the literature in 1974 by Liegeois et al, ${ }^{83}$ to describe a small proportion of chimeric cells in the recipient blood. The presence of microchimerism is far from insignificant; there is much evidence that the cumulative effect of microchimeric cells is substantial, especially after liver transplantation, when they are most easily demonstrated.

\section{Metabolic Effects}

The small population of chimeric cells has been shown to affect total body metabolism in patients treated with liver transplantation for the enzyme deficiencies of type IV glycogen storage disease and Gaucher's disease. In these diseases, the consequences of the missing enzymes are widespread storage of amylopectin and glucocerebroside, respectively. ${ }^{11}$ The disorders were previously thought to be treatable only by bone marrow transplantation because the enzyme deficiency affects all cells; however, 2-8 years after liver replacement, there was a dramatic resorption of both kinds of storage material from host tissues (Fig $27-$ 8). As an explanation for the metabolic amelioration, chimeric donor cells were found to be ubiquitous in recipient tissues, including those of the heart, lymph nodes, bone marrow, intestine, and skin (see Fig 27-5). There apparently had been a coculture effect of a small number of chimeric donor cells on the contiguous, overwhelming numbers of enzyme-deficient recipient cells.

\section{The Immunological Interface}

The foregoing metabolic observations raised important questions about the potential cell-to-cell effects of other molecules directly involved in immunological rather than metabolic processes, including those subserving tolerance induction (see Fig 27-1). Perhaps such questions could be answered if it were known how the chimeric donor cells, many of which resemble dendritic cells, are perpetuated for as long as 3 decades after transplantation. The dendritic cells and other leukocytes could be spawned by small numbers of pluripotent progenitor cells coming from the allograft interstitium. Dendritic cell precursors have been grown from mouse blood, bone marrow, or whole organs using media enriched with granulocyte/ macrophage colony-stimulating factor. ${ }^{84}$ The products of these stem cells should reach terminal differentiation, however, unless there is a reason for their continued proliferation. We have suggested that the subsequent survival and renewal of these cells depend on continuous mutual stimulation of the donor and recipient cell populations ${ }^{13}, 15$ in a process of tolerization that shares many of the cellular characteristics associated with immunity. ${ }^{85}$

\section{CHANGED HOST AND GRAFT INTERACTIONS}

There are indirect ways to show that the coexisting immunocyte populations in successful cases (see Fig 27-1) come to regard each other in a revised light. The evidence, on the one hand, is the fading of the threat of clinical rejection concomitant with development of donor-specific nonreactivity in spite of lightened treatment (or, in some animal models, without any treatment); on the other hand, the evidence is the waning specter of GVHD. It is quite natural to expect that the threat of GVHD and rejection would decline contemporaneously in an organ recipient because both of the cell populations are receiving the same protective immunosuppression. Appreciation of the two-cell population relationship and the need not to alter it by ablating one side or the other was the crucial advance made empirically that permitted the successful engraftment of leukocyte-rich organs such as the liver, intestine, both together, or all of the intra-abdominal organs (multivisceral transplantation). ${ }^{86}$ Once the cardinal principle was understood that low-level mixed allogeneic chimer-
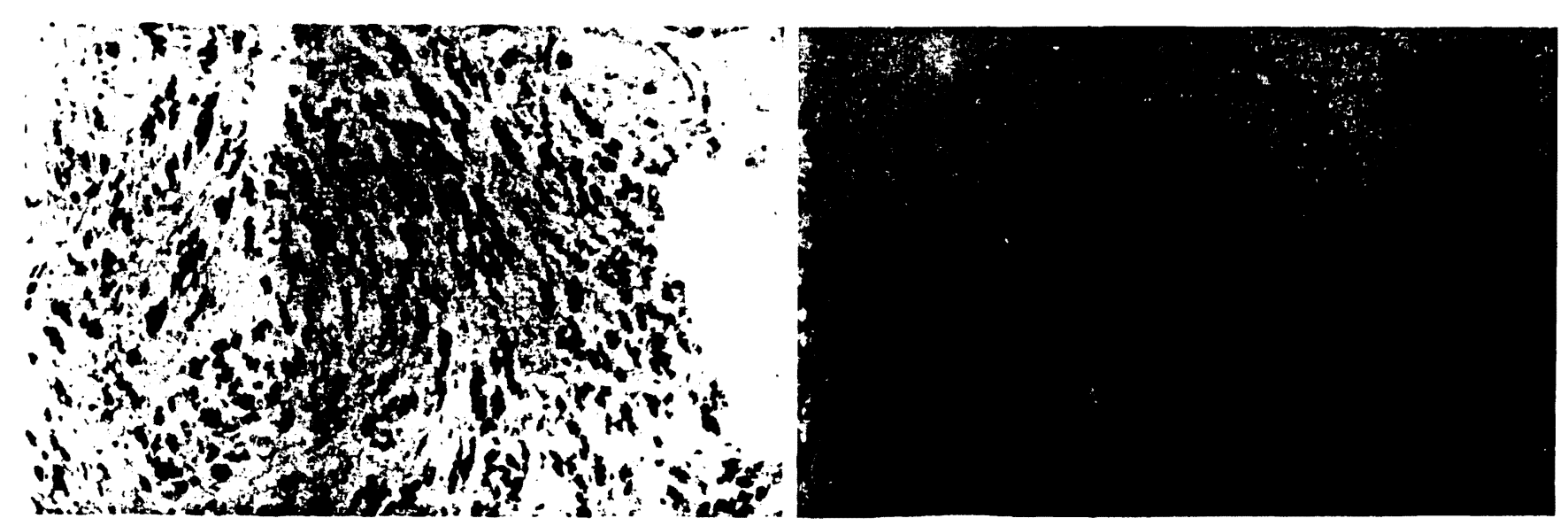

Figure 27-8 A, An endomyocardial biopsy specimen obtained in 1989, at the time of liver transplantation, revealed diffuse amylopectin deposits within and between cells. $B$, Another endomyocardial biopsy specimen obtained in 1992 revealed only traces of extracellular deposits (penodic acid-Schiff-D, $\times 100$ ). (From Starzl TE, Demetris AJ, Trucco M, et al. Chimerism after liver transplantation for type IV glycogen storage and type I Gaucher's disease. Reprinted with permission from The New England Journal of Medicine, 328.745-749 and 1993.) 
ism was invariably found after the successful transplantation of any whole organ, the reason GVHD was not common in liver, intestinal, or multivisceral recipients seemed obvious. Mixed chimerism was being produced empirically in the way that had been documented in the classic GVHD-free mouse bone marrow mixed chimerism models of Slavin et $\mathrm{al}^{87}$ and Ildstad and Sachs. ${ }^{88}$

\section{THE CRITICAL DENDRITIC CELL}

The generation of an immune response leading, under normal circumstances, to graft destruction, GVHD, or both, requires effective antigen presentation and recognition in its initial phase; this signal is followed by a second, costimulatory signal and the response of $T$ cells to the combined signal. ${ }^{89}$ Both of these signals are normally delivered to $T$ cells by professional antigen-presenting cells. Of these cells, the dendritic cell ${ }^{56-58}$ (the most prominent chimeric cell by morphological criteria ${ }^{9-15}$ ) is critical because it can modify the expression of cell interaction, major histocompatibility complex, and adhesion molecules, all of which determine how antigen signals are heeded by $\mathrm{T}$ cells. $^{59}$ The dendritic leukocyte is thus the prime candidate in this tolerogenicity scenario, even though other lineages may also be essential for a successful outcome.

\section{IMPACT ON TISSUE MATCHING}

In the directions of both host-versus-graft (HVG) and graft-versus-host (GVH) rejection, cellular interactions resulting in mutual natural immunosuppression are envisioned as occurring on a sliding scale with each further level of histoincompatibility (Fig 27-9). With effective immunosuppression, it has become increasingly possible throughout the last 3 decades to mitigate the alloreactions enough to allow the tolerogenic changes to occur after mutual cell engagement and to allow a rapprochement to be reached between the coexisting immunocytes. The anticipated histocompatibility influence on both rejection and the severity of GVHD is then expected to dwindle. We have postulated, 12-14 that this dwindling influence explains the poor correlation of HLA matching with outcome after the cadaveric transplantation of whole organs, including the kidney ${ }^{90-92}$ With regard to liver transplantation, two large centers have actually reported an inverse relationship between the quality of HLA matching and the clinical outcome. ${ }^{93,94}$

\section{RELATION OF CELL MIGRATION TO TOLERANCE}

The inadequacy of thymic clonal deletion to explain acquired transplantation tolerance has been emphasized in a
Figure 27-9 The donor-recipient leukocyte interaction is a buffer against rejection on the one hand and graftversus-host disease on the other. Veto and suppressor cells are postulated to be the result of the interaction shown at the cell population interface. $R_{x}=$ iatrogenic immunosuppression. (Reprinted from Immunology Today, 14, Starzl TE. Demetris AJ, Murase N, et al, Donor cell chimerism permitted by immunosuppressive drugs: $A$ new view of organ transplantation. 326-332.

Copyright 1993, with kind permission from Elsevier Science Ltd. The Boulevard. Langtord Lane, Kidlington OX5 1GB. UK.)
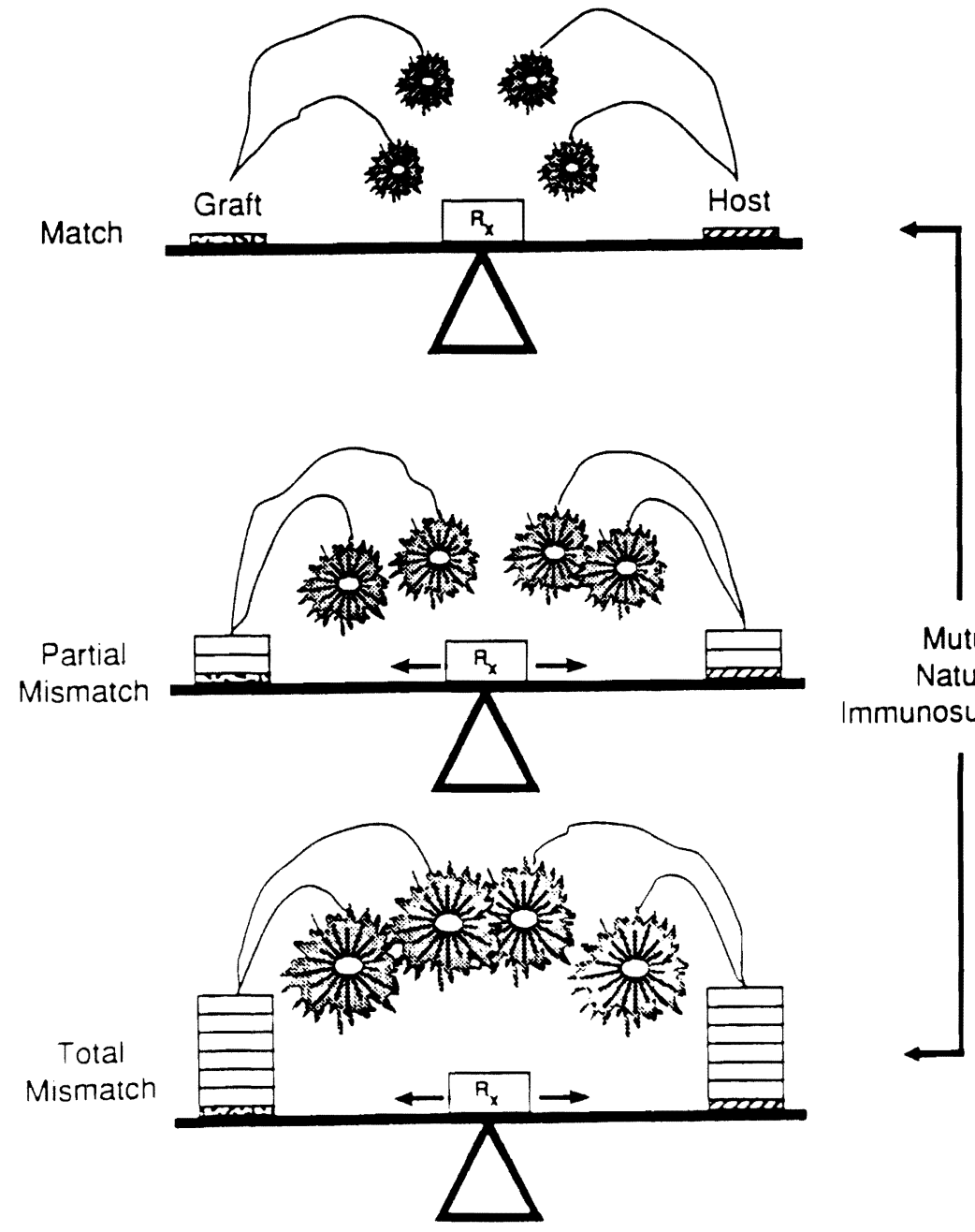

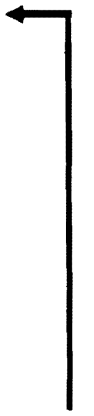

Mutual

Natural

Immunosuppression 
1992 review.95 Although a discussion of the meaning of tolerance is beyond our intention, it should be noted that all of the mechanisms that explain clonal silencing, including peripheral (nonthymic) clonal deletion and anergy, could mesh with the discovery of the enduring grafthost intimacy inherent with chimerism. The production of suppressor cells, veto cells, or both could be an epiphenomenological consequence. Evidence of the long-term vitality and turnover of donor leukocytes in recipient tissues is particularly supportive of the opinions of Bandeira et al, ${ }^{85}$ Coutinho, ${ }^{96}$ and Cohen, ${ }^{97}$ who have defined acquired tolerance as a high (not anergic) level of sustained immune activity in immunological networks. These networks presumably interact in a more complex way than do the idiotype systems originally postulated by Jerne.98

Apart from explaining why the events of convalescence follow the same pattern after all transplantations, no matter what the organ, the cell migration-chimerism concept shows how donor-specific nonreactivity can be achieved with a common mechanism, regardless of the site of action of the immunosuppressive drugs administered, or, in some experimental models, without drugs at all. It has been proposed on the basis of observations in drug-free models of tolerance induction that $\mathrm{T}$ cell receptor occupancy leads to the production of negative regulators of interleukin (IL)-2 production (anergy proteins). ${ }^{89},{ }^{99}$ According to this hypothesis, during the course of a normal T cell response (to alloantigens) these negative regulators of IL-2 production have an inconsequential effect because they are diluted by vigorous cell replication driven by IL- 2 . However, these negative regulators would accumulate with consequent anergy if clonal expansion were prevented at any level (Fig 27-10), for instance, by the absence of a costimulatory signal in drug-free models. ${ }^{89}$

The same effect could be induced iatrogenically by pharmacological interdiction of IL-2 gene transcription (cyclosporine and FK506) or by the administration of a DNA synthesis inhibitor (azathioprine, cyclophosphamide, and numerous others). The use of monoclonal antibodies that do not deplete T cells, such as those directed against the cell surface CD4 antigen, or monoclonal antibodies that are directed against adhesion molecules, including intercellular adhesion molecule 1 and lymphocyte function related antigen 1 (LFA-1), ${ }^{100}$ can also be envisaged.

However it occurs, the reciprocal educational process of donor and recipient leukocytes and its perpetuation resemble, in the direction of either rejection or GVHD (see Fig $27-10$ ), the "infectious" transplantation tolerance of Waldmann and Cobbold. which can be passed on to naive lymphocytes and be self-sustaining in some circumstances. ${ }^{101}$ It is postulated that in fully successful cases, the mini-immune system of the graft is incorporated into the existing recipient immunological network. ${ }^{13.15}$ a concept compatible with the hypothesis of Coutinho. ${ }^{96}$

\section{UNSTABLE MIXED CHIMERISM}

Cell migration conceptually reunites bone marrow transplantation and whole organ transplantation. We believe that there are not different mechanisms involved in successful engrattment and that these two seemingly dis-

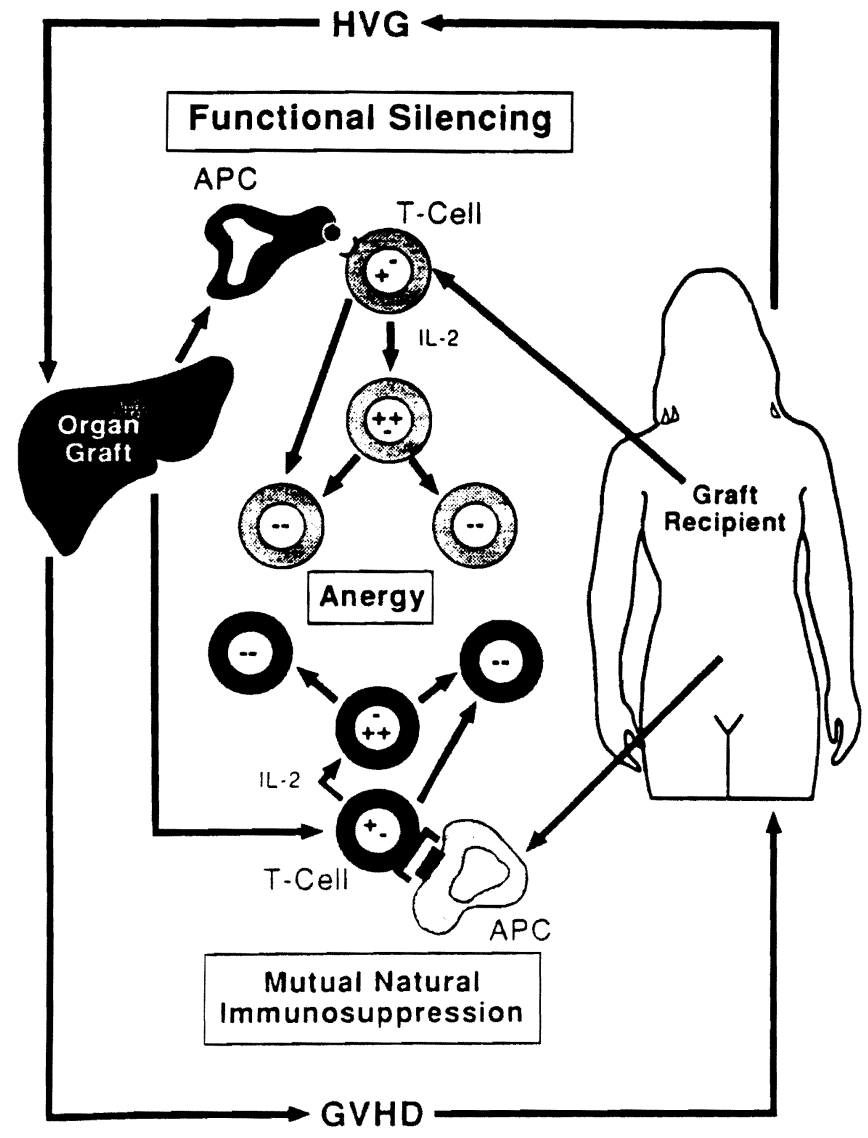

Figure 27-10 Model of dendritic cell antigen-presenting-cell-T cell interaction, showing the production within the nucleus of positive $(+)$ and negative ( - ) regulators (anergy proteins) of interleukin-2 (IL-2) gene transcription. In this model, anergy relates only to the IL-2 gene, and other cytokines (eg, interferon- $\gamma$ ) may be secreted, albeit at suboptimal levels. In the absence of persistent costimulatory signals (or under the umbrella of immunosuppressive drugs), cell division does not proceed and negative nuclear regulators accumulate, resulting in $T$ cell anergy. In addition to the action of immunosuppressive agents, chronic antigen stimulation is envisaged as promoting anergy. In some instances, tolerance can be broken, for example, by administration of exogenous IL-2. HVG = host versus graft response (allograft rejection). (From Thomson, AW, Demetris AJ, Murase N, Starzl TE. Promotion of cell chimerism by immunosuppression drugs: A possible basis for tolerance induction following organ transplantation. In Thomson AW. Starzl TE, eds. Immunosuppressive Drugs: Developments in Anti-Rejection Therapy. London, Edward Amold. 1994, p 226. Reproduced by permission of Edward Amold [Publishers] Limited.)

parate clinical disciplines merely reflect contrasting treatment dogmas (Fig 27-11). For bone marrow transplantation, the conventional treatment strategy of recipient cytoablation eliminates mutual immunocyte engagement and thus necessitates heavy reliance on HLA matching to prevent GVHD in the unbalanced system. The treatment of solid organ transplantation encourages. or at least permits. these consequences of mutual cell engagement and thereby liberates the patient from the restrictions of HLA matching and from an overwhelming threat of GVHD.

Failure of the chimeric and recipient immunocytes to reach an immunological truce (see Fig $27-1$ ) leads to re- 
Figure 27-11 The division of transplantation into two separate disciplines by divergent therapeutic dogmas that created one-way versus two-way in vivo mixed lymphocyte response analogues. The policies used in bone marrow transplantation inhibited or precluded bidirectional cell migration, whereas this phenomenon formed the fundamental basis of graft acceptance in whole organ transplantation. (From Starzl TE, Demetris AJ, Trucco M, et al. Cell migration and chimerism after whole organ transplantation: The basis of graft acceptance. Hepatology 17:1127-1152, 1993.)

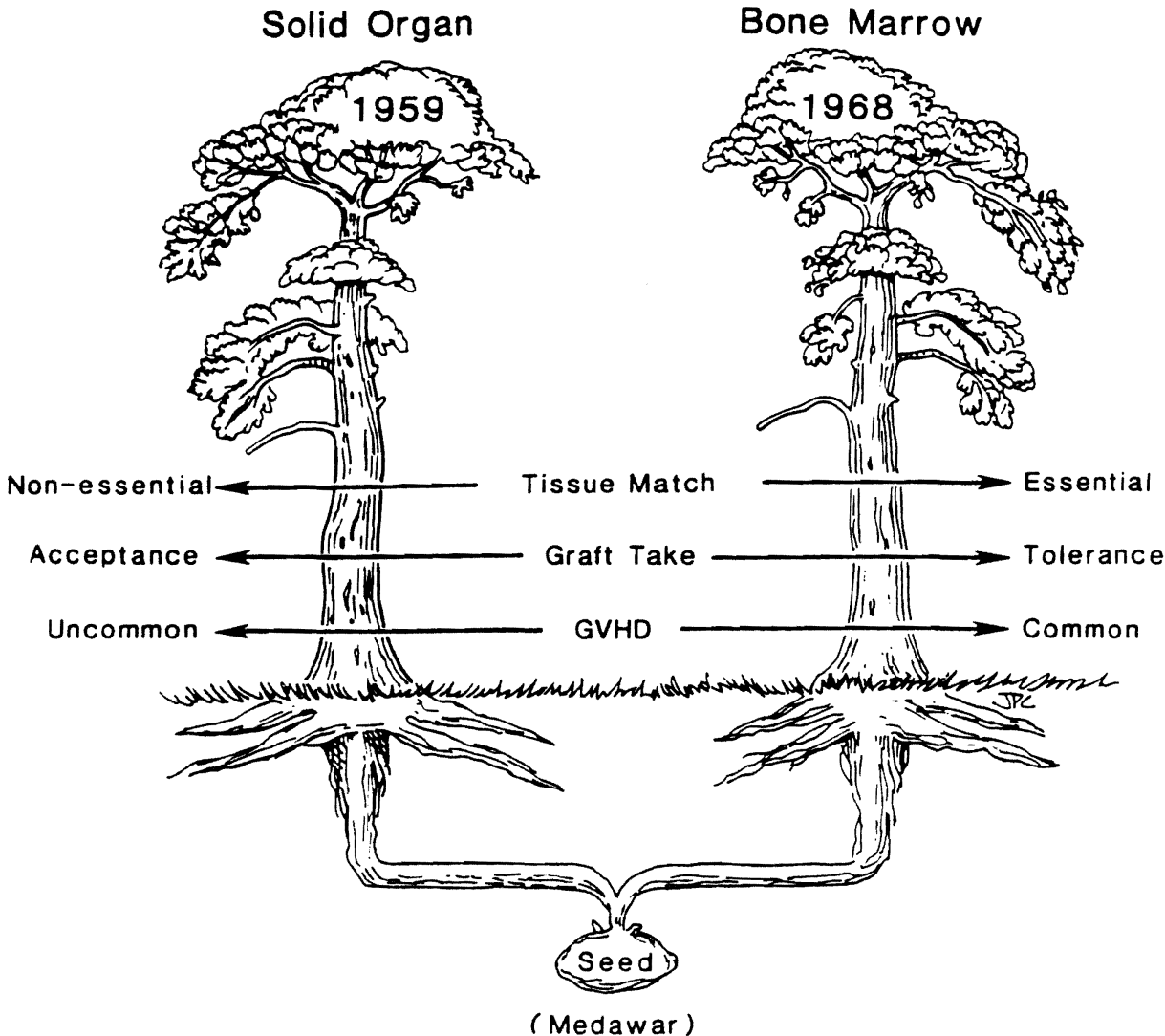

jection of the transplanted whole organ on the one hand, or to GVHD on the other; sometimes, it leads to both simultaneously. This phenomenon has been particularly well studied after intestinal transplantation between certain rat strain combinations involving the BN strain. ${ }^{36-38}$ In ACI, PVG, or LEW rats treated daily with variable doses of FK 506 for 14 days and weekly thereafter, successful intestinal transplantation from fully allogeneic BN donors was not complicated by either rejection or fatal GVHD. ${ }^{38}$ In contrast, when the BN strain was the recipient. rejection of the $\mathrm{ACI}$ intestine was difficult to control, and when LEW or PVG intestine was transplanted, GVHD invariably developed after daily treatment was stopped. The two-way lymphocyte traffic from graft to host lymphoid organs and vice versa was similar with either strain direction. ${ }^{36,37}$ Saat et a ${ }^{102}$ have described analogous findings of GVHD predisposition and rejection with the use of cyclosporine after WAG to $\mathrm{BN}$ rat intestinal transplantation but not BN to WAG.

Further experiments in our laboratory have not clarified why the $\mathrm{BN}$ rat is an easy donor but a difficult recipient. At a clinical level, the unresolved practical question is how to identify and avoid bad donor-recipient combinations analogous to LEW, ACI. or PVG to BN rats. particularly when immunologically active organs such as the liver and intestine are engrafted.

With human liver transplantation, preoccupation with rejection long obscured the fact that the GVH reaction. which is an incipient process and. in our opinion. a requisite for sustained engraftment in every case. can evolve to serious or fatal syndromes ${ }^{103-110}$ in the early postoperative period. Clinically significant GVHD is observed in our liver program in approximately $5 \%$ of cases, manifesting as dermatitis. ${ }^{14}$ In the past. this dermatitis was usually attributed to a self-limiting drug reaction or was considered an allergic manifestation.

Although most of these patients can be treated successfully with increased immunosuppression (particularly prednisone), or occasionally by decreasing treatment. liver recipients with extensive skin involvement, gastrointestinal symptoms, and depression of the formed blood elements have high mortality. ${ }^{108}$ The chimerism that has been documented in such patients has differed only by being more extensive than that seen in patients who have a benign convalescence.

The potential adverse consequences of deliberately unbalancing the donor-recipient interface were illustrated by the case of a 56-year-old man with gastric leiomyosarcoma and liver metastases who underwent a liver transplantation after an upper abdominal exenteration. ${ }^{111}$ Just before the operation, the recipient was prepared with a single dose of 550-rad thoracoabdominal lymphoid irradiation followed by an intravenous dose of $19 \times 10^{9}$ nonpurged bone marrow cells. Several weeks postoperatively, he developed progressive and grave GVHD with more than $80 \%$ skin involvement that did not respond to increased or decreased immunosuppression. On days 42 and 43 after surgery, respectively, $1.23 \times 10^{8}$ and $1.6 \times 10^{8}$ unpurged bone marrow cells per kilogram (collected and stored from before the preoperative total lymphoid irradiation) were infused intravenously. The rash dramatically resolved over the next 2 weeks. coincident with a fall in mixed lin- 
eage donor cells in the blood from approximately $25 \%$ of total to $3 \%$ by flow cytometry, without the advent of rejection.

The ability of the stored autologous marrow cells to turn off the potentially lethal GVHD may be a clue to the changes that occur during the mutual cell engagement of mixed chimerism. Although the cells used for rescue from GVHD were thought to be smaller in number than those in the circulation of the patient, they had not been exposed to donor marrow. Their therapeutic effect resembled the ability of virgin donor strain immunocytes to "break tolerance," as originally described by Billingham et al. ${ }^{112}$

Two clinically relevant lessons from this traumatic experience have been reported elsewhere. ${ }^{111}$ The first was the inadvisability of trying to make space for the augmenting marrow cells with total lymphoid irradiation. The second lesson was the potential value of naive autologous bone marrow, which can be stored as a safety net should GVHD occur. These lessons have guided further attempts at bone marrow augmentation for the induction of tolerance in whole organ recipients.

\section{CLINICAL TRIALS OF BONE MARROW AUGMENTATION}

\section{Kidney Alone or Kidney Plus Pancreatic Islets}

The concept developed in this chapter is that the content (and perhaps the specific lineages) of migratory cells, which are particularly numerous in the liver, confers potential immunological advantages. These passenger leukocytes, which are of bone marrow origin, have been considered an immunological liability for transplantation ${ }^{54-67}$; however, under the appropriate conditions, they may be tolerogenic, as exemplified by the liver. A corollary, therefore, is that organs such as the kidney and heart, which have a smaller leukocyte component, could be brought to the liver's tolerogenic potential. In fact, the frequently advanced strategy of intravenously infusing donor bone marrow, donor blood (donor-specific transfusion), or other hematolymphoid cells at the same time or shortly after the transplantation of whole organ $\mathrm{s}^{83}$, 87, 88, 113-116 is merely an augmentation of the normal posttransplantation cell migration. To mimic the natural process. these cells should be given perioperatively, not in advance or afterward, as has usually been done with the Monaco experimental model. ${ }^{114-116}$

\section{CLINICAL EXPERIENCE}

Since December 1992 at our center, four patients with end-stage renal disease have received a simultaneous kidney-bone marrow allograft from the same cadaveric donor. In addition, two diabetic (type I) renal patients were given pancreatic islets from their kidney-bone marrow donor. As a precaution. autologous bone marrow was harvested from all the recipients immediately before the kidney transplantation and cryopreserved for potential future use in case of GVHD, ${ }^{11}$ as described in the preceding section.

The donor bone marrow was obtained from vertebral bodies at the end of multiorgan procurement, and $3 \times 10^{8}$ untreated bone marrow cells were infused intravenously immediately after the kidney transplantation. The two diabetic patients received the additional pancreatic islet infusion intraportally at the time of the intravenous bone marrow infusion. All six patients were treated with FK 506 and prednisone. Chimerism was assessed in the recipients by flow cytometry, polymerase chain reaction, and immunostaining with peripheral blood lymphocytes. Immunological monitoring was done by mixed lymphocyte response and cell-mediated lympholysis.

None of these patients exhibited GVHD. Detectable levels of donor cells were present in the peripheral blood lymphocytes of all six recipients during the 1- to 6-month follow-up. Donor cells were also detected in two patients whose lymph nodes were biopsied 2 and 4 months after transplantation. All six patients and their renal grafts are doing well. The two patients who were also given pancreatic islets have been treated too recently to evaluate their insulin status accurately.

Further evaluation of passenger leukocyte augmentation (with bone marrow and other leukocyte sources) is of particular interest for pancreatic islet transplantation, which has consistently failed as a means of treating diabetes because of the high rate of rejection. ${ }^{117}$ If it is possible to increase islet allograft survival with minimal ultimate immunosuppression by concomitant donor bone marrow infusion, this will be an approach opposite to the numerous attempts to reduce islet immunogenicity by selective destruction of the antigen-presenting cells derived from bone marrow that are normally contained in islet preparations. ${ }^{118}$ Donor bone marrow would then become a dosemaneuverable component of any organ or cellular transplantation for the facilitation of graft acceptance and for the induction of donor-specific nonreactivity.

\section{A LIVER TRANSPLANTATION ROAD MAP FOR DRUG WEANING}

As discussed earlier, past experience with conventional liver transplantation can be envisioned as a mini-bone marrow engraftment. In one reported group of 44 human liver recipients who had survived from 11 to 23 years, 6 (14\%) had stopped all immunosuppression between 1 and 11 years postoperatively and had subsequently experienced clinically stable, drug-free intervals of $5-13$ years; another 15 patients were drug free and stable after a shorter follow-up period. ${ }^{14}, 119$ The most extreme example of early successful drug discontinuance in a liver recipient was after 6 months, with a subsequent follow-up period of 3 years. A trial of drug weaning has been started in liver recipients with a rejection-free course exceeding 5 years. Liver graft rejection (if it occurs) can be so effectively treated with FK $506^{120}$ that the benefits of drug weaning appear to us to outweigh the risks in selected patients.

This liver experience should provide insight regarding the use of bone marrow augmentation to achieve freedom from immunosuppression in recipients of organs and cells such as the kidney or pancreatic islets. Even when drug weaning has been decided upon, there is presently no way to know when a potential drug-free state has arrived. It seems clear that, if the clinical experience with the tolerogenic livers is taken seriously, kidney or heart transplantation plus bone marrow augmentation will also require 
protracted immunosuppression before the treatment can be stopped altogether and that, even then, it can be stopped only with precautions. Such conclusions have also been reached by Barber et al, ${ }^{116}$ who used delayed supplementary bone marrow for cadaveric kidney transplantation as advocated by Monaco et al. ${ }^{114,115}$

\section{Liver Transplantation}

\section{CLINICAL EXPERIENCE}

Two liver recipients have received the same doses of perioperative bone marrow as patients in the kidney series, and 500-550 Gy total lymphoid irradiation was added preoperatively. The second patient developed nearly fatal GVHD from which he was rescued with stored autologous bone marrow (see under Unstable Mixed Chimerism). One year later, the patient underwent retransplantation for hepatitis $C$ virus infection. The biopsy revealed predominantly hepatitis, but there were also signs of vascular rejection. Blood chimerism was no longer detectable immediately before retransplantation, even by polymerase chain reaction.

The unwise decision made regarding this patient and the second one to unbalance the donor-recipient interface iatrogenically with total lymphoid irradiation was based on the dogma that making space would facilitate engraftment of the marrow. This concept has been eroded by direct experimentation. ${ }^{121,}{ }^{122}$ The second patient, now 13 months after surgery, has had a perfect clinical result since biopsy findings showed mild rejection at 2 weeks. She takes a daily dose of $6 \mathrm{mg}$ of FK506 plus $5 \mathrm{mg}$ of prednisone. There is evicience of chimerism in the peripheral blood lymphocytes by cytospin.

Three additional patients underwent liver transplantation and bone marrow augmentation without total lymphoid irradiation. Their courses have been uncomplicated, with the exception of one episode of rejection 2 weeks after transplantation. All are blood chimeras.

\section{RISKS AND BENEFITS}

The augmentation in liver recipients of a process of cell migration and chimerism that is already highly operational after this kind of transplantation must be closely monitored for efficacy. Whether leukocyte augmentation will do more than could be achieved naturally in tolerance induction (with earlier achievement of a drug-free state) or will only increase the risk of GVHD remains to be determined. The storage of autologous bone marrow for rescue should GVHD occur appears to be a mandatory precaution in such trials. ${ }^{11}$

\section{References}

1. Weber RA, Cannon JA. Longmire WP. Observations on the regrafting of successtul homografts in chickens. Ann Surg 139:473-477, 1954

2. Murray JE. Sheil AGR. Moseley R, et al. Analysis of mechanism of immunosuppressive drugs in renal homotransplantation. Ann Surg 160:449-473, 1964.

3. Stard TE. Host-graft adaptation. In Starz TE, ed. Experience in Renal Transplantauon. Philadelphia. WB Saunders, 1964, pp 164-170.

4. Stard TE. Efforts to mitigate or prevent rejection. In Starz TE. ed. Experience in Hepatuc Transplantation. Philadelphia. WB Saunders, 1969. pp 203-233.
5. Levey RH. Immunological tolerance and enhancement: A common mechanism. Transplant Proc 3:41-48, 1971.

6. Murase N, Kim DG, Todo S, et al. FK 506 suppression of heart and liver allograft rejection. Part 2, The induction of graft acceptance in the rat. Transplantation 50:739-744, 1990.

7. Streilein JW. Neonatal tolerance of $\mathrm{H}-2$ alloantigens. Procuring graft acceptance the "old-fashioned" way. Transplantation 52:1-10, 1991.

8. Eto M, Mayumi H, Nishimura $Y$, et al. Similarity and difference in the mechanisms of neonatally induced tolerance and cyciophosphamide-induced tolerance in mice. J Immunol 147:2439-2446, 1991.

9. Stard TE, Demetris AJ, Murase N, et al. Cell migration, chimerism, and graft acceptance. Lancet 339:1579-1582, 1992.

10. Starzl TE, Demetris AJ, Trucco M, et al. Systemic chimerism in human female recipients of male livers. Lancet 340:876-877, 1992.

11. Stard TE, Demetris AJ, Trucco M, et al. Chimerism after liver transplantation for type IV glycogen storage disease and type I Gaucher's disease. N Engl J Med 328:745-749, 1993.

12. Starzl TE, Demetris AJ, Trucco M, et al. Chimerism and donor specific nonreactivity 27 to 29 years after kidney allotransplantation. Transplantation 55:1272-1277, 1993.

13. Starzl TE, Demetris AJ, Murase N, et al. Donor cell chimerism permitted by immunosuppressive drugs: A new view of organ transplantation. Immunol Today 14:326-332, 1993.

14. Starzl TE, Demetris AJ, Trucco M, et al. Cell migration and chimerism after whole organ transplantation: The basis of graft acceptance. Hepatology 17:1127-1152, 1993.

15. Demetris AJ, Murase N, Fujisaki S, et al. Hematolymphoid cell trafficking, microchimerism, and GVHD reactions after liver, bone marrow, and heart transplantation. Transplantation Proc 25:3337-3344, 1993.

16. Porter KA. Pathology of the orthotopic homograft and heterograft. In Starzl TE, ed. Experience in Hepatic Transplantation. Philadelphia, WB Saunders, 1969, pp 427-437.

17. Kashiwagi N, Porter KA, Penn I, et al. Studies of homograft sex and of gamma globulin phenotypes after orthotopic homotransplantation of the human liver. Surg Forum 20:374-376, 1969.

18. Murase N, Demetris AJ, Matsuzaki T, et al. Long survival in rats after multivisceral versus isolated small bowel allotransplantation under FK 506. Surgery 110:87-98, 1991.

19. Iwaki Y, Starz TE, Yagihashi A, et al. Replacement of donor lymphoid tissue in human small bowel transplants under FK 506 immunosuppression. Lancet 337:818-819,1991.

20. Randhawa PS, Stard TE, Ramos $\mathrm{H}$, et al. Allografts surviving for 26-29 years following living related kidney transplantation: Analysis by light microscopy, in situ hybridization for the $Y$ chromosome, and anti-HLA antibodies. Am J Kidney Dis 24:72-77, 1994.

21. Fung JJ, Zeevi A, Kaufman C, et al. Interactions between bronchoalveolar lymphocytes and macrophages in heart-lung transplant recipients. Human Immunol 14:287-294, 1985.

22. Demetris AJ, Murase N, Stard TE. Donor dendritic cells in grafts and host lymphoid and non-lymphoid tissues after liver and heart allotransplantation under short term immunosuppression. Lancet 339:1610, 1992.

23. Valdivia LA. Demetris AJ, Langer AM, et al. Dendritic cell replacement in long-surviving liver and cardiac xenografts. Transplantation 56:482-484, 1993.

24. Sinclair RA. Origin of endothelium in human renal allografts. BMJ 4:15-16, 1972.

25. Sedmak DD, Sharma HM, Czajka CM, Ferguson RM. Recipient endothelialization of renal allografts: An immunohistochemical study utilizing blood group antigens. Transplantation 46:907-909, 1988.

26. Andersen CB, Ladefoged DS, Larsen S. Cellular inflammatory infiltrates and renal cell turnover in kidney allografts: A study using in situ hybridization and combined in situ hybridization and immunohistochemistry with a Y. chromosome-specific DNA probe and monoclonal antibodies. APMIS 99:645-652, 1991

27. Thomas J. Carver M. Cunningham P, et al. Promotion of incompatible allograft acceptance in rhesus monkeys given post-transplant antithymocyte globulin and donor bone marrow: I. In vivo parameters and immunohistologic evidence suggesting microchimerism. Transplantation 43:332. 1987.

28. Wilson WEC. Kirkpatrick $\mathrm{CH}$. Immunologic aspects of renal homotrans plantation. In Starz TE, ed. Experience in Renal Transpiantation. Philadelphia. WB Saunders. 1964, pp 239-261.

29. Lawrence HS. The transfer of hypersensitivity of the delayed type in man. In Lawrence HS, ed. Cellular and Humoral Aspects of the Hypersensitive States. New York. Hoeber-Harper, 1959, p 279.

30. Kashiwagi N. Special immunochemical studies. In Starzl TE, ed. Experience in Hepauc Transplantation. Philadelphia. WB Saunders, 1969. pp 394-407.

31. Ramsey G. Nusbacher J, Starz TE, Lindsay GD. Isohemagglutinins of graf origin after ABO-unmatched liver transplantation. N Engl J Med 311:1167 1170. 1984

32. Davies HAS, Polland SG, Calne RY. Soluble HLA antigens in the circulation of liver graft recipients. Transplantation 47:524-527, 1989.

33. Russo C. Pellegnno MA. Ferrone S. A double-determinant immunoassay with monocional antubodies to the HLA-A. -B, -C complex. Transpiant Proc 15:66-68, 1983. 
34. Krangel MS. Secretion of HLA-A and -B antigens via an alternative RNA splicing pathway. J Exp Med 163:1173-1190, 1986.

35. Singh PB, Brown RE, Roser B. Class I transplantation antigens in solution in body fluids and in the urine. J Exp Med 168:195-211, 1988.

36. Murase N, Demetris AJ, Wo J, et al. Lymphocyte traffic and graft-versusbost disease after fully allogeneic small bowel transplantation. Transplant Proc 23:3246-3247, 1991.

37. Murase N, Demetris A, Woo J, et al. Graft versus host disease (GVHD) after BN to LEW compared to LEW to BN rat intestinal transplantation under FK 506. Transplantation 55:1-7, 1993.

38. Tanabe M, Murase N, Demetris AJ, et al. The influence of donor and recipient strains in isolated small bowel transplantation in rats. Transplant Proc 26:4325-4332, 1994.

39. Graver B. World Transplant Records - 1991: Kidney. In Terasaki PA, Cecka JM, eds. Clinical Transplants. Los Angeles, UCLA Press, 1991, p 431.

40. Starzl TE, Marchioro TL, Porter KA, et al. Factors determining short- and long-term survival after orthotopic liver homotransplantation in the dog. Surgery 58:131-155, 1965 .

41. Qian S, Demetris AJ, Murase N, et al. Murine liver allograft transplantation: Tolerance and donor cell chimerism. Hepatology 19:916-924, 1994.

42. Valdivia LA, Fung JJ, Demetris AJ, Stard TE. Differential survival of hamster-to-rat liver and cardiac xenografts under FK 506 immunosuppression. Transplant Proc 23:3269-3271, 1991.

43. Garnier H, Clot J, Bertrand M, et al. Liver transplantation in the pig: Surgical approach. C R Acad Sci, Paris 260:5621 - 5623, 1965.

44. Peacock JH, Terblanche J. Orthotopic homotransplantation of the liver in the pig. In Read AE, ed. The Liver. London, Butterworth, 1967, pp 333-336.

45. Calne RY, White HJO, Yoffa DE, et al. Observations of orthotopic liver transplantation in the pig. BMJ 2:478-480, 1967.

46. Zimmerman FA, Butcher GW, Davies HS, et al. Techniques for orthotopic liver transplantation in the rat and some studies of the immunologic responses to fully allogeneic liver grafts. Transplant Proc 11:571-577, 1979.

47. Murase N, Demetris AJ, Kim DG. et al. Rejection of the multivisceral allograft in rats: A sequential analysis with comparison to isolated orthotopic small bowel and liver grafts. Surgery 108:880-889, 1990.

48. Starzl TE, Ishikawa M, Putnam CW, et al. Progress in and deterrents to orthotopic liver transplantation, with special reference to survival, resistance to hyperacute rejection, and biliary duct reconstruction. Transplant Proc 6:129$139,1974$.

49. Kamada N, Davies HfIS, Roser B. Reversal of transplantation immunity by liver grafting. Nature 292:840-842, 1981.

50. Houssin D, Gugenheim J, Bellon B, et al. Absence of hyperacute rejection of liver allografts in hypersensitized rats. Transplant Proc 17:293-295, 1985.

51. Fung J, Makowka L, Tzakis A, et al. Combined liver-kidney transplantation: Analysis of patients with preformed lymphocytotoxic antibodies. Transplant Proc 20(Suppl 1):88-91, 1988.

52. Calne RY, Sells RA, Pena JR, et ai. Induction of immunological tolerance by porcine liver allografts. Nature 233:472-474, 1969.

53. Valdivia L, Demetris AJ. Fung JJ, et al. Successful hamster to rat liver xenotransplantation under FK 506 immunosuppression induces unresponsiveness to hamster heart and skin. Transplantation 55:659-661, 1993.

54. Snell GD. The homograft reaction. Annu Rev Microbiol 11:439-458. 1957.

55. Steinmuller D. Immunization with skin isografts taken from tolerant mice. Science 158:127-129.1967.

56. Steinman RM, Cohn ZA. Identification of a novel cell type in peripheral lymphoid organs of mice. I. Morphology, quantitation, tissue distribution. J Exp Med 137:1142-1162, 1973.

57. Steinman RM, Cohn ZA. Identification of a novel cell type in peripheral lymphoid organs of mice. Il. Functional properties in vitro. J Exp Med 139:380-397, 1974

58. Steinman RM. Lustig DS. Cohn ZA. Identification of a novel cell type in peripheral lymphoid organs of mice. III. Functional properties in vivo. J Exp Med 139:1431-1445, 1974.

59. Steinman RM. The dendritic cell system and its role in immunogenicity. Annu Rev Immunol 9:271 -296, 1991.

60. Hart DNJ, McKenzie JL. Interstitial dendritic cells. Int Rev Immunol 6:128 149. 1990.

61. Hart DNJ, Winearis CG. Fabre JW. Graft adaptation: Studies on possible mechanisms in long-term surviving rat renal allografts. Transplantation 30:73-80, 1980 .

62. Batchelor JR. Welsh KJ, Maynard A, Burgos H. Failure of long surviving, passively enhanced allografts to provoke T-dependent alloimmunity: I. Retranspiantation of (AS $\times$ AUG)F1 kidneys into secondary AS recipients. J Exp Med 150:455-464, 1979.

63. Lechler RI, Batchelor JR. Restoration of immunogenicity to passenger cell depleted kidney allografts by the addition of donor-strain dendritic cells. J Exp Med 155:31-41, 1982.

64. Talmage DW, Dart G, Radovich J. Lafferty KJ. Activation of transplant immunity: Effect of donor leukocytes on thyroid allograft rejection. Science 191:385-387, 1976.

65. Lafferty KJ. Bootes A. Dart G. Talmage DW. Effect of ongan culture in the survival of thyroid allogratts in mice. Transplantation 22:138-149.1976.

66. Faustman D, Hauptfeld V, Lacy P. Davie J. Prolongation of murine islet allograft survival by pretreatment of islets with antibody directed to la determinants. Proc Natl Acad Sci U S A 78:5156-5159. 1981.
67. Austyn JM, Steinman RM. The passenger leukocyte - a fresh look. Transpl Rev 2:139-176, 1988.

68. Marchioro TL, Rowlands DT Jr, Rifkind D, et al. Splenic homotransplantation. Ann N Y Acad Sci 120:626-651, 1964.

69. Wakely E, Oberholser JH, Corry RJ. Elimination of acute GVHD and prolongation of rat pancreas allograft survival with DST, cyclosporine, and spleen transplantation. Transplantation 49:241-245, 1990.

70. Bitter-Suermann H, Save-Soderbergh JS. The course of pancreas allografts in rats conditioned by spleen allografts. Transplantation 26:28-34, 1978.

71. Prop J, Kuijpers K, Petersen AH, et al. Why are lung allografts more vigorously rejected than hearts? Heart Transplant 4:433-436, 1985.

72. Westra AL, Prop J, Kuijpers KC, Wildevuur CRH. A paradox in heart and lung rejection. Transplantation 49:826-828, 1990.

73. Nemlander A, Soots A, von Willebrand E, et al. Redistribution of renal allograft-responding leukocytes during rejection. II. Kinetics and specificity. J Exp Med 156:1087-1100, 1982.

74. Larsen CP, Morris PJ, Austyn JM. Migration of dendritic leukocytes from cardiac allografts into host spleens. A novel route for initiation of rejection. J Exp Med 171:307-314, 1990.

75. Demetris AJ, Qian S, Sun $\mathrm{H}$, et al. Early events in liver allograft rejection. Am J Pathol 138:609-618, 1991.

76. Forbes RD, Parfiey NA, Gomersail M, et al. Dendritic cell-lymphoid aggregation and major histocompatibility antigen expression during rat cardiac allograft rejection. J Exp Med 164:1239-1258, 1986.

77. van Schlifgaarde $R$, Hermans $P$, Terpstra JL, et al. Role of mobile passenger lymphocytes in the rejection of renal and cardiac allografts in the rat. Transplantation 29:209-213. 1980.

78. Hayry $P$, von Willebrand $E$ : Transplant aspiration cytology in the evaluation of a renal allograft. In Touraine JL. Traeger J, Betuel H, et al, eds. Transplantation and Clinical Immunology, vol 15. Amsterdam. Excerpta Medica, 1983, pp 124-137.

79. von Willebrand E, Taskinen E, Ahonen J, Hayry P. Recent modifications in the fine needle aspiration biopsy of human renal allografts. Transplant Proc 15:1195-1197, 1983

80. Corry RJ, Winn HJ, Russell PS. Primary vascularized allografts of hearts in mice: The role of H-2D, $\mathrm{H}-2 \mathrm{~K}$ and non $-\mathrm{H}-2$ antigens in rejection. Transplantation 16:343-350, 1973.

81. Russell PS, Chase CM, Colvin RB, Plate JMD. Kidney transplants in mice. An analysis of the immune status of mice bearing long-term G-2 incompatible transplants. J Exp Med 147:1449-1468, 1978.

82. Russell PS. Modification of runt disease in mice by various means. Ciba Found Symp 1962, pp 350-383.

83. Liegeois A, Charreire J, Brennan LB. Allograft enhancement induced by bone marrow cells. Surg Forum 25:297-300. 1974

84. Inaba K, Inaba M, Romani N, et al. Generation of large numbers of dendritic cells from mouse bone marrow cultures supplemented with granulocyte/macrophage colony-stimulating factor. J Exp Med 176:1693-1702, 1992.

85. Bandeira A, Coutinho A, Carnaud C. et al. Transplantation tolerance correlates with high levels of T- and B-lymphocyte activity. Proc Natl Acad Sci U S A 86:272-276, 1989

86. Starzl TE. Todo S. Tzakis A, et al. The many faces of multivisceral transpiantation. Surg Gynecol Obstet 172:335-344, 1991.

87. Slavin S. Strober S, Fuks Z, Kaplan HS. Induction of specific tissue transplantation tolerance using fractionated total lymphoid irradiation in adult mice: Long-term survival of allogeneic bone marrow and skin grafts. J Exp Med 146:34-48. 1977

88. Ildstad ST, Sachs DH. Reconstitution with syngeneic plus allogeneic or xenogeneic bone marrow leads to specific acceptance of allografts or xenografts. Nature 307:168-170, 1984.

89. Jenkins MK. The role of cell division in the induction of clonal anergy. Im munol Today 13:69-73, 1992

90. Matas AJ. Sutherland DER, Najarian JS. The impact of HLA matching on graft survival. Transplantation 54:568-569. 1992.

91. Ferguson R. Transplant Information Share Group (TISG). A multicenter experience with sequential ALG/cyclosporine therapy in renal transplantation. Clin Transpl 2:285-294, 1988.

92. Salvatierra O, Jr. Optimal use of organs for transplantation. N Engl J Med 318:1329-1331, 1988.

93. Donaldson PT, O'Grady J, Portmann B, et al. Evidence for an immune response to HLA class I antigens in the vanishing bile duct syndrome after liver transplantation. Lancet 1:945-948, 1987.

94. Markus BH. Duquesnoy RJ, Gordon RD. et al. Histocompatibility and liver transplant outcome. Does HLA exern a dualistic effect? Transplantation 46:372-377. 1988 .

95. Miller JF. Morahan G. Peripheral T cell tolerance. Annu Rev Immunol 10:51 - 69. 1992.

96. Coutinho A. Beyond clonal selection and network. Immunol Rev $110: 63-87$, 1989.

97. Cohen IR. The cognitive paradigm and the immunological homunculus. Immunol Today 13:490-494, 1992.

98. Jeme NK. Idiotypic networks and other preconceived ideas. Immunol Rev $79: 5-24,1984$

99. Zubiaga AM. Munoz A. Huber BT. Superinduction of IL-2 gene transcription in the presence of cycloheximide. J Immunol 146:3857-3863. 1991.

100. Isobe M. Yagia H. Okumura K. Ihara A. Specific acceptance of cardiac allo 
graft after treatment with antibodies to ICAM-1 and LFA-1. Science 255:1125-1127, 1992.

101. Waldmann H, Cobbold $\mathrm{S}$. The use of monoclonal antibodies to achieve immunological tolerance. Immunol Today 14:247-251, 1993.

102. Saat RE, De Bruin RWF, Heineman E, et al. The limited efficacy of cyclo sporine in preventing rejection and graft-versus-host disease in orthotopic small bowel transplantation in rats. Transplantation 50:374-377, 1990.

103. Burdick JF, Vogelsang GB, Smith WJ, et al. Severe graft-versus-host disease in a liver transplant recipient. N Engl J Med 319:689-691, 1988.

104. Marubayashi S, Matsuzaka C. Fatal generalized acute graft recipient. Transplantation 50:709-711, 1990 .

105. Bhaduri BR. Tan KC, Humphreys S, et al. Graft-versus-host disease after orthotopic liver transplantation in a child. Transplant Proc 22:2378-2380, 1990.

106. Roberts JP, Ascher NL, Lake J, et al. Graft vs. host disease after liver transplantation in humans: A report of four cases. Hepatology 14:274-281, 1991

107. Jamieson NV, Joysey V, Friend PJ, et al. Graft-versus-host disease in solid organ transplantation. Transplant Int 4:67-71, 1991.

108. Rosen CB, Moore SB, Batts KP, et al. Clinical and pathological features of graft-versus-host disease after liver transplantation: A case report and review of the literature. Clin Transpl 7:52-58, 1993.

109. Comenzo RL, Malachowski ME, Rohrer RJ, et al. Anomalous ABO phenotype in a child after an ABO-incompatible liver transplantation. N Engl J Med 326:867-889, 1992.

110. Collins RH, Anastasi J, Terstappen LW, et al. Brief report: Donor-derived long-term multilineage hematopoiesis in a liver-transplant recipient. N Engl J Med 328:762-765, 1993.

111. Ricordi C, Tzakis AG, Demetris AJ, et al. Reversal of graft-versus-host disease with infusion of stored autologous bone marrow cells following combined liver-bone marrow allotransplantation in man. Transplant Sci 3:76-77, 1993.
112. Billingham R, Brent $L$, Medawar $P$. Quantitative studies on tissue transplantation immunity. III. Actively acquired tolerance. Philos Trans $R$ Soc Lond Biol 239:357-412, 1956.

113. Monaco AE, Wood ML, Russell PS. Studies of heterologous anti-lymphocyte serum in mice. III. Immunologic tolerance and chimerism produced across the $\mathrm{H}-2$ locus with adult thymectomy and anti-lymphocyte serum. Ann N Y Acad Sci 129:190-209, 1966.

114. Monaco AP, Wood ML. Studies on heterologous antilymphocyte serum in mice: VII. Optimal cellular antigen for induction of immunologic tolerance with ALS. Transplant Proc 2:489-496, 1970.

115. Monaco AP, Wood ML, Maki T, Gozzo JJ. Post transplantation donor-specific bone marrow transfusion in polyclonal antilymphocyte serum - treated recipients: The optimal cellular antigen for induction of unresponsiveness to organ allografts. Transplant Proc 20:1207-1212, 1988.

116. Barber WH, Mankin JA, Laskow DA, et al. Long term resuits of a controlled prospective study with transfusion of donor-specific bone marrow in 57 cadaveric renal allograft recipients. Transplantation 51:70-75, 1991.

117. Carroll PB, Ricordi C, Shapiro R, et al. Frequency of kidney rejection in diabetic patients undergoing simultaneous kidney and islet cell transplantation. Transplantation 55:761-765, 1993.

118. Ricordi C, Ildstad ST, Starz TE. Induction of pancreatic islet graft acceptance: The role of antigen presenting cells. Transplant Sci 2:34-38, 1992.

119. Reyes J, Zeevi A, Tzakis A, et al. The frequent achievement of a drug free state after orthotopic liver transplantation. Transplant Proc 25:3315-3319, 1993.

120. Starz TE, Todo S, Fung J, et al. FK 506 for human liver, kidney and pancreas transplantation. Lancet 2:1000-1004, 1989.

121. Harrison DE. Competitive repopulation in unirradiated normal recipients (editorial). Blood 81:2473-2474, 1993.

122. Stewart FM, Crittenden RB, Lowry PA. Long-term engraftment of normal and post-5-fluorouracil murine marrow into normal nonmyeloablated mice. Blood 81:2566-2571, 1993. 